\title{
Low-dose theophylline modulates T-lymphocyte activation in allergen-challenged asthmatics
}

\author{
Z.H. Jaffar, P. Sullivan, C. Page, J. Costello
}

\begin{abstract}
Low-dose theophylline modulates T-lymphocyte activation in allergen-challenged asthmatics. Z.H. Jaffar, P. Sullivan, C. Page, J. Costello. @ CERS Journals Ltd 1996.

ABSTRACT: Theophylline has been shown by several investigators to attenuate the late asthmatic response (LAR) to inhaled allergen, suggesting that it has antiinflammatory or immunomodulatory properties. We have, therefore, undertaken a double-blind, placebo-controlled study to examine the effects of low-dose theophylline on bronchoalveolar lavage (BAL) and blood T-lymphocyte profile and activation in asthmatics following antigen challenge and the development of a LAR.

Peripheral blood and BAL samples were obtained from 17 subjects with mild atopic asthma before and after 6 weeks of treatment with either oral theophylline or placebo. The mean serum theophylline concentration achieved was $6.6 \mu \mathrm{g} \cdot \mathrm{mL}^{-1}$, which is below the currently accepted therapeutic range.

Following theophylline therapy, there was a significant decrease in the number of BAL lymphocytes compared to placebo. On flow cytometric analysis of BAL cells, a significant loss of CD3+ T-lymphocytes, comprising both CD4+ and CD8+ subsets, was demonstrated. Moreover, there was a decrease in the number of BAL CD4+ T-cells expressing the activation marker very late activation antigen-1 (VLA-1), and an apparent reduction in human leucocyte antigen-DR (HLA-DR). Correspondingly, this was accompanied in the blood by an elevation in the proportion of activated CD4+ T-lymphocytes, in particular those expressing HLA-DR.

These findings provide further evidence that theophylline has an anti-inflammatory action in asthma.
\end{abstract}

Eur Respir J., 1996, 9, 456-462.

Dept of Thoracic Medicine, King's College Hospital, London, UK.

Correspondence: Z.H. Jaffar

University Medicine

Level D, Centre Block

Southampton General Hospital

Southampton SO16 6YD

UK

Keywords: Asthma

bronchoalveolar lavage

immunomodulation

T-lymphocytes

theophylline

Received: January 121995

Accepted after revision November 241995

This study was supported by Napp Laboratories, Cambridge, UK.
Allergen inhalation challenge of subjects with atopic asthma can provoke an early asthmatic response (EAR), which is measurable as an immediate decrease in forced expiratory volume in one second (FEV1). This is often followed by a second and persistent fall in FEV1, occurring $2-6 \mathrm{~h}$ after antigen exposure [1-3]. Whereas the early bronchoconstrictor response is primarily due to mediator release from activated mast cells $[4,5]$, the late asthmatic response (LAR) is accompanied by the infiltration and activation of various inflammatory cell types in the airways [6-8]. Such inhalational challenge is commonly used as an experimental model to unravel inflammatory processes involved in asthma.

It is now well-recognized that inflammatory events play a central role in the pathogenesis of asthma, and early treatment with anti-inflammatory agents is currently recommended [9]. Theophylline, a drug widelyused in asthma therapy for its bronchodilator effects, has been demonstrated at therapeutic concentrations to inhibit the activity of several immunocompetent cells in a number of experimental and clinical situations [10-12]. Indeed, there is increasing evidence that theophylline attenuates the LAR to inhaled allergen [13-15]. Recently, in our laboratories, this inhibition was achieved at serum concentrations below the conventional range for bronchodilation and was demonstrated to have an immunomodulatory role, possibly through regulation of T-lymphocyte activation [15].

T-lymphocytes, of a TH2-like phenotype [16], are thought to play an important role in orchestrating the asthmatic inflammatory response. Immunoglobulin $\mathrm{E}$ (IgE) antibody production by B-lymphocytes and the activation and recruitment of granulocytes to the lungs, particularly eosinophils, are under the influence of Tcell derived cytokines. With their capacity to release basic proteins and lipid mediators, eosinophils are implicated in the epithelial damage and bronchial hyperresponsiveness characteristic of asthma [17, 18]. An in-creased number of activated CD4+ T-cells has been identified in peripheral blood of patients with acute severe asthma [19]. In addition, analysis of blood and bronchoalveolar lavage (BAL) lymphocytes in atopic asthmatics after allergen exposure has revealed that CD4+ T-cells are depleted in the circulation and sequestered in the lung [20, 21]. Moreover, an elevation in CD8+ T-lymphocytes was observed in subjects who developed isolated early asthmatic responses but not in dual and late phase-responders, leading the investigators to propose that $\mathrm{CD} 8+$ cells function to downregulate or suppress the LAR [22]. We have, therefore, undertaken 
a double-blind, placebo-controlled study to investigate the effect of low-dose oral theophylline treatment on the expression of phenotypic and activation surface markers in peripheral blood and BAL T-lymphocytes in atopic asthmatics after allergen challenge. The effects of theophylline on the inflammatory cell population and mediator levels in BAL fluid obtained after LAR was also examined. This report supplements our preliminary study [23], which investigated the effect of theophylline on the recruitment and activation of inflammatory cells in the bronchial mucosa of these asthmatics.

\section{Material and methods}

\section{Subjects}

Nineteen subjects with mild asthma (FEV1 $>80 \%$ predicted) participated in the study and were selected on the basis of having positive skin-prick tests to house dust mite extract, Dermatophagoides pteronyssinus (Der p) and exhibiting a LAR to the inhaled allergen. This was documented during a screening challenge performed at least 2 weeks prior to participating in the main study. The challenge was performed using increasing concentrations of nebulized allergen until a $15 \%$ reduction in FEV1 occurred. The LAR was then defined as a secondary fall in FEV1 of at least $20 \%$ from baseline occurring within $7 \mathrm{~h}$ of challenge. Control challenge with diluent was also performed to document baseline variability. Subjects were excluded if they had more than a $10 \%$ fall in FEV1 after diluent inhalation. All readings for FEV1 were expressed as a percentage of postdiluent values. The subjects had not experienced an exacerbation of their asthma or respiratory tract infection at least 6 weeks prior to entry into the trial. They were all nonsmokers, using only inhaled $\beta_{2}$-agonists medication as required. Caffeine intake was withheld $12 \mathrm{~h}$ before and during each visit. Informed written consent was obtained from all subjects before participation and the study was approved by the Ethics Committee of King's College Hospital.

Two individuals from the placebo group withdrew from the study, one due to exacerbation of asthma during the treatment period and the other due to becoming wheezy after the first bronchoscopy.

\section{Study protocol}

On commencement of the study (Day 1) subjects were challenged with Der p (Pharmacia, Milton Keynes, UK) using a concentration previously shown to produce an EAR and LAR. Subjects inhaled allergen solution by tidal breathing for 2 min through a Wright nebulizer calibrated to an output of $0.13 \mathrm{~mL} \cdot \mathrm{min}^{-1}$. Measurements of FEV1 were recorded using a dry wedge bellows spirometer (Vitalograph) before challenge, then at $5 \mathrm{~min}$ intervals for $15 \mathrm{~min}, 10 \mathrm{~min}$ intervals for the first hour, and thereafter at $30 \mathrm{~min}$ intervals until $6 \mathrm{~h}$ after challenge. Peripheral blood samples were taken at baseline (prechallenge) and at EAR, LAR and $24 \mathrm{~h}$ postchallenge, for total and differential leucocyte counts (Coulter Counter) and for flow cytometric analysis of T-cells. Bronchoscopy and BAL were performed $24 \mathrm{~h}$ (Day 2) after allergen challenge. Subjects then received either slow-release oral theophylline (Uniphyllin Continus tablets, $200 \mathrm{mg}$ b.i.d.; Napp Laboratories, UK) or placebo for 6 weeks in a double-blind, randomized manner, after which they reattended the laboratory for a repeat of Days 1 and 2. Plasma theophylline levels were checked by Acculevel, without the investigators' knowledge, on two separate occasions during the treatment period to confirm compliance with the drug regimen. Tablet counts were also performed. To calibrate final steady-state theophylline concentrations, plasma levels were measured on the last day of the study, $4 \mathrm{~h}$ after the last dose. Records of inhaled $\beta_{2}$-agonist usage and morning and evening peak expiratory flow rates (PEFR) were kept in diary cards throughout the study.

\section{Bronchoscopy and bronchoalveolar lavage}

Fibreoptic bronchoscopy was performed $24 \mathrm{~h}$ after antigen challenge by the same operator in all patients. Each subject was premedicated with atropine $(0.6 \mathrm{mg}$, intravenously) and nebulized salbutamol $(2.5 \mathrm{mg}) 15 \mathrm{~min}$ before the procedure. Mild sedation was achieved with intravenously administered midazolam or alfentanil, and supplementary oxygen was given throughout the procedure. Patient oxygenation was monitored by pulse oximetry. After applying $4 \%$ lignocaine spray to the nose and throat of the subject, the flexible bronchoscope (Olympus BF P20D, Tokyo, Japan) was introduced. Local anaesthesia of the larynx was achieved with topical $4 \%$ lignocaine, whilst a $2 \%$ solution was used below the vocal cords to suppress coughing. The bronchoscope was wedged in the medial segment of the right middle lobe. BAL was then performed with three $60 \mathrm{~mL}$ aliquots of warmed $\left(37^{\circ} \mathrm{C}\right)$ sterile saline $(0.9 \% \mathrm{NaCl})$. The fluid was aspirated by gentle suction and collected into a siliconized glass flask cooled on ice. Salbutamol solution (2.5 $\left.\mathrm{mg} \cdot \mathrm{mL}^{-1}\right)$ was instilled through the bronchoscope after lavage if local bronchoconstriction had developed. Subjects were observed for $3 \mathrm{~h}$ after bronchoscopy before discharge from the hospital.

\section{Sample processing}

BAL fluid was gently shaken to homogeneity, filtered through nylon gauze to remove any mucus and the remaining volume was recorded. After removing a $1 \mathrm{~mL}$ aliquot for differential cell counts, the sample was centrifuged immediately at $200 \times \mathrm{g}$ for $10 \mathrm{~min}$. The cell pellet was resuspended in phosphate-buffered saline (PBS, $1 \mathrm{~mL}$ ) to be used for flow cytometric analysis, and the aliquoted supernatant was snap-frozen under liquid nitrogen and stored at $-70^{\circ} \mathrm{C}$ pending mediator measurement.

Total nucleated cells were counted using an improved Neubauer haemocytometer and their viability assessed 
by trypan blue exclusion. Differential counts were performed on cytocentrifuge preparations (Shandon Cytospin II) using $100 \mu \mathrm{L}$ of cell suspension and centrifugation at $800 \mathrm{rpm}$ for $5 \mathrm{~min}$. After air-drying, two slides per BAL sample were stained with Diff Quick (Browns, Reading, UK) and 1,000 cells were counted by scanning several fields of view. Mast cell counts were made on slides stained with alcian blue after fixation in Carnoy's solution. Cell counts were performed by the same observer throughout and were validated by an independent investigator.

Supernatants were thawed immediately before use for the determination of the following eosinophil and mast cell mediators, using commercially available radioimmunoassay kits: eosinophil cationic protein (ECP), tryptase (both Pharmacia Diagnostics, Milton Keynes, UK), histamine (Serotec, Kidlington, UK); and prostaglandin $\mathrm{D}_{2}\left(\mathrm{PGD}_{2}\right.$; Amersham, Aylesbury, UK).

\section{Flow cytometry}

Specific binding of monoclonal antibodies (MoAbs) was analysed by dual colour immunofluorescence staining to identify T-lymphocytes bearing phenotypic (CD3/ CD4, CD3/CD8) and activation (CD4/human leucocyte antigen-DR (HLA-DR), CD4/very late activation antigen1 (VLA-1) or CD8/HLA-DR, CD8/VLA-1) surface markers. Whole blood or BAL cells in volumes of $100 \mu \mathrm{L}$ were incubated in the dark for $15 \mathrm{~min}$ in the presence of saturating amounts of MoAbs directly conjugated with fluorescein isothiocyanate (FITC) or phycoerythrin (PE). The mouse MoAbs used were: anti-CD3-PE, CD4FITC, CD8-FITC, HLA-DR-PE, CD4-PE, CD8-PE (all Becton Dickinson, Oxford, UK) and VLA-1-FITC (Lab Impex, Teddington, UK). Erythrocyte lysis was then achieved by the addition of $2 \mathrm{~mL}$ of lysing solution (FACS lysing solution, Becton Dickinson). Following incubation for a further $10 \mathrm{~min}$ at room temperature, cells were centrifuged at $250 \times \mathrm{g}$ for $5 \mathrm{~min}$ and washed twice in PBS pH 7.2 (Cell Wash; Becton Dickinson). Stained cells were then fixed with $500 \mu \mathrm{L}$ of $1 \%$ paraformaldehyde in sheath fluid (FACSFlow, Becton Dickinson), equilibrated at $4^{\circ} \mathrm{C}$ and analysed within $24 \mathrm{~h}$.

Flow cytometric analysis of T-cells for the surface immunofluorescence was performed on a Becton Dickinson FACScan equipped with an air-cooled argon-ion laser and detectors for forward scatter (FSC), $90^{\circ}$ light scatter (side scatter, SSC), fluorescence FL1 (530 nm wavelength, green) and FL2 (585 nm, red/orange). Lymphocytes were identified by their characteristic appearance on a dot plot of FSC versus SSC and electronically gated to exclude contaminating monocytes, granulocytes or red cell debris. A minimum of 10,000 gated events (lymphocytes) were acquired and analysed using Consort 30 software. Lymphocytes stained with FITC- and PElabelled MoAbs were detected on the FL1 and FL2 channels, respectively. Results were expressed as percentage positive cells excluding nonspecific staining, assessed using isotype control antibodies (Becton Dickinson) directed against an irrelevant target. An aliquot of cells was stained with anti-CD14-FITC (Becton Dickinson) to assess monocyte or macrophage contamination of the lymphocyte gate, which was always $<2 \%$. Using the total lymphocyte count, the absolute number of T-cells expressing the various cell surface markers were calculated per $\mathrm{mL}$ of BAL fluid recovered.

Although 17 individuals completed the study, for technical reasons flow cytometric data were not obtained from one subject.

\section{Statistical analysis}

Spirometry data, which were normally distributed, was compared by a paired Student's t-test. Changes in cell counts, mediator levels and flow cytometry data within the theophylline or placebo group were examined by the Wilcoxon-rank sign test for paired data. Differences occurring between the two treatment groups were expressed as percentages of their respective baselines and compared by the Mann-Whitney U-test. Differences were considered significant when the p-value was less than 0.05 .

\section{Results}

\section{Clinical data}

The clinical characteristics of the study population are shown in table 1 . After allergen challenge, there were no statistically significant differences in symptom scores, daily PEFR value, or rescue medication use between the treatment groups, which is not surprising in view of the clinically mild condition of the study population. There was a trend towards an improvement in FEV1 during the LAR at $6 \mathrm{~h}$ in the theophylline group $(\mathrm{p}=0.055)$, however no significant change was observed in the placebo group (fig. 1). Baseline FEV1 following theophylline treatment was significantly higher than in those subjects receiving placebo $(\mathrm{p}<0.05)$ (data not shown). The mean final steady-state serum theophylline concentration was $6.6 \mu \mathrm{g} \cdot \mathrm{mL}^{-1}$ (range $4.0-8.3 \mu \mathrm{g} \cdot \mathrm{mL}^{-1}$ ), which is below the currently regarded therapeutic range $\left(10-20 \mu \mathrm{g} \cdot \mathrm{mL}^{-1}\right)$. Using low-dose theophylline, the side-effects associated with therapy were negligible and none of the subjects opted to discontinue the study medication. A more detailed account of these results has been presented elsewhere [23].

Table 1. - Clinical characteristics of the study population

\begin{tabular}{lcc}
\hline & \multicolumn{2}{c}{ Treatment group } \\
& Theophylline & Placebo \\
\hline Age yrs & $26(20-43)$ & $27(22-36)$ \\
Sex F/M & $4 / 6$ & $5 / 2$ \\
Baseline FEV1 \% pred & $94(81-114)$ & $97(81-115)$ \\
\hline
\end{tabular}

Values are presented as mean with range in parenthesis. FEV1: forced expiratory volume in one second; $\%$ pred: percentage of predicted value. 

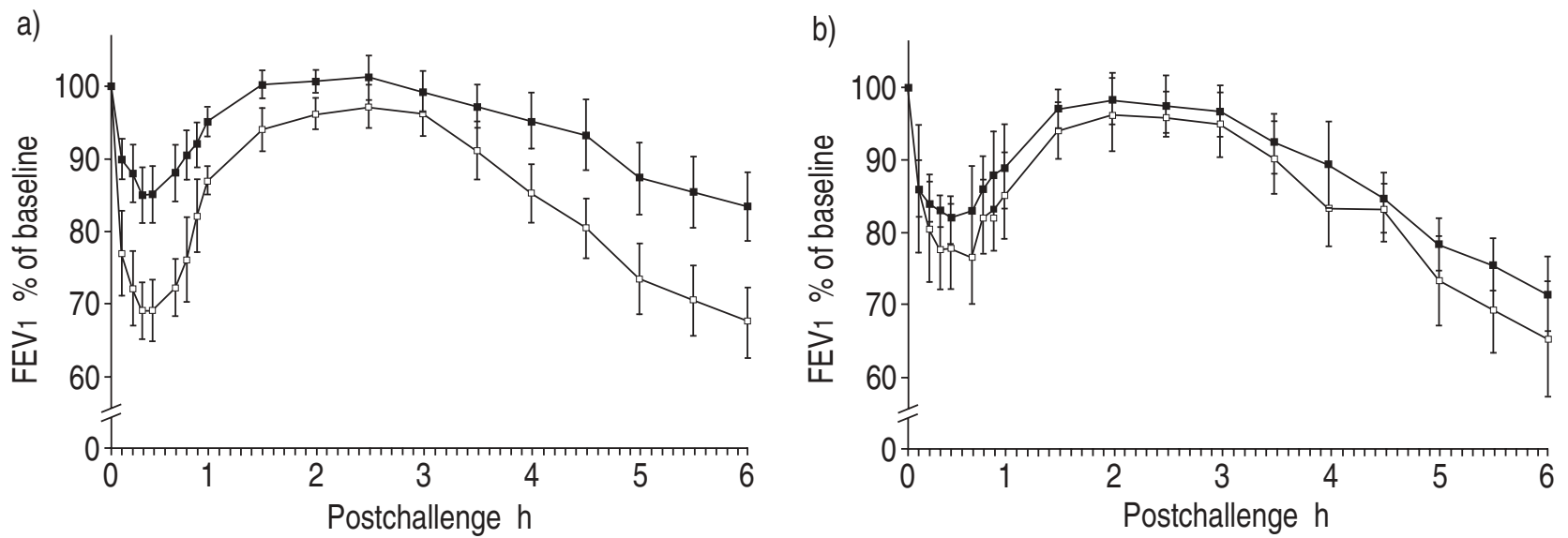

Fig. 1. - Changes in mean FEV1 before ( $\square$ ) and after ( $\square$ ) treatment with: a) theophylline or b) placebo. Curve for early and late asthmatic responses are shown as percentage fall in FEV1 from prechallenge baseline following allergen challenge. Error bars represent SEM. FEV1: forced expiratory volume in one second.

\section{$B A L$ mediator levels}

There were no statistically significant differences between the two treatment groups in the BAL concentration of ECP, histamine, tryptase and $\mathrm{PGD}_{2}$, although a trend towards a decrease in the levels of these mediators was observed after theophylline therapy (table 2).

\section{BAL cellular profile}

Following theophylline treatment, there was a reduction in the overall number of BAL lymphocytes $\cdot \mathrm{mL}^{-1}$ of fluid compared to placebo, and the treatment-induced changes between the groups were significant $(\mathrm{p}=0.013)$. Although there was also a fall in the percentage of lymphocytes

Table 2. - BAL fluid eosinophil and mast cell mediator levels pre- and post-treatment with either theophylline or placebo

\begin{tabular}{lcccc}
\hline Mediator & \multicolumn{2}{c}{ Theophylline group $(\mathrm{n}=10)$} & \multicolumn{2}{c}{ Placebo group $(\mathrm{n}=7)$} \\
& Pretreatment & Post-treatment & Pretreatment & Post-treatment \\
\hline ECP $\mathrm{ng} \cdot \mathrm{mL}^{-1}$ & 17.0 & 12.2 & 16.0 & 20.0 \\
& $(4.0-62.0)$ & $(1.2-70.0)$ & $(2.2-56.0)$ & $(10.0-180)$ \\
Histamine $\mathrm{ng} \cdot \mathrm{mL}^{-1}$ & 2.8 & 2.1 & 1.3 & 2.9 \\
& $(0.5-15.0)$ & $(0.2-10.0)$ & $(0.5-6.6)$ & $(0.4-4.3)$ \\
Tryptase $\mathrm{ng} \cdot \mathrm{mL}^{-1}$ & 2.7 & 2.1 & $(0-2.8)$ & $(0.1-8.6)$ \\
& $(0-10.5)$ & $(0.1-15.0)$ & 7.6 & 12.0 \\
$\mathrm{PGD}_{2} \mathrm{pg} \cdot \mathrm{mL}^{-1}$ & 11.0 & 11.8 & $(1.0-33.0)$ & $(2.0-47.0)$ \\
& $(3.4-60.0)$ & $(0-50.0)$ & & \\
\hline
\end{tabular}

All values are expressed as median, with range shown in parenthesis. No significant differences were found between the treatment groups. ECP: eosinophil cationic protein; $\mathrm{PGD}_{2}$ : prostaglandin $\mathrm{D}_{2}$; $\mathrm{BAL}$ : bronchoalveolar lavage.

Table 3. - Volume of BAL fluid recovered, total cell yield, viability and differential cell counts pre- and post-treatment with theophylline or placebo

\begin{tabular}{|c|c|c|c|c|}
\hline & \multicolumn{2}{|c|}{ Theophylline group $(n=10)$} & \multicolumn{2}{|c|}{ Placebo group $(\mathrm{n}=7)$} \\
\hline & Pretreatment & Post-treatment & Pretreatment & Post-treatment \\
\hline Volume $\mathrm{mL}$ & $93.7 \pm 9.6$ & $82.8 \pm 10.9$ & $95.4 \pm 8.6$ & $101.0 \pm 7.4$ \\
\hline Viability \% & $70 \pm 5$ & $74 \pm 4$ & $70 \pm 2$ & $73 \pm 5$ \\
\hline Total cells $\times 10^{5} \cdot \mathrm{mL}^{-1}$ & $1.8 \pm 0.2$ & $1.7 \pm 0.2$ & $1.5 \pm 0.2$ & $2.6 \pm 0.8$ \\
\hline Macrophages \% & $67 \pm 4$ & $71 \pm 5$ & $64 \pm 4$ & $67 \pm 5$ \\
\hline$\times 10^{4} \cdot \mathrm{mL}^{-1}$ & $12.1 \pm 1.5$ & $11.5 \pm 1.2$ & $8.9 \pm 0.9$ & $15.2 \pm 2.9$ \\
\hline Lymphocytes \% & $17 \pm 3$ & $12 \pm 1$ & $15 \pm 3$ & $14 \pm 2$ \\
\hline$\times 10^{4} \cdot \mathrm{mL}^{-1}$ & $2.7 \pm 0.4$ & $1.9 \pm 0.3 *$ & $2.2 \pm 0.5$ & $3.5 \pm 1.2$ \\
\hline Neutrophils \% & $3.1 \pm 0.7$ & $3.9 \pm 2.4$ & $4.2 \pm 2.4$ & $3.6 \pm 1.5$ \\
\hline$\times 10^{4} \cdot \mathrm{mL}^{-1}$ & $0.6 \pm 0.2$ & $1.1 \pm 0.8$ & $0.6 \pm 0.4$ & $1.2 \pm 0.7$ \\
\hline Eosinophils \% & $5.7 \pm 1.7$ & $6.3 \pm 3.5$ & $13.0 \pm 4.1$ & $10.6 \pm 4.9$ \\
\hline$\times 10^{4} \cdot \mathrm{mL}^{-1}$ & $1.0 \pm 0.3$ & $1.2 \pm 0.7$ & $2.2 \pm 0.9$ & $4.8 \pm 3.8$ \\
\hline Epithelial cells \% & $6.9 \pm 2.7$ & $6.8 \pm 3.0$ & $3.8 \pm 0.9$ & $4.8 \pm 1.3$ \\
\hline$\times 10^{4} \cdot \mathrm{mL}^{-1}$ & $1.6 \pm 0.8$ & $1.2 \pm 0.5$ & $0.6 \pm 0.5$ & $0.9 \pm 0.3$ \\
\hline
\end{tabular}

All values are presented as mean \pm SEM. *: $\mathrm{p}<0.05$, for comparison of treatment effect between groups. BAL: bronchoalveolar lavage fluid. 


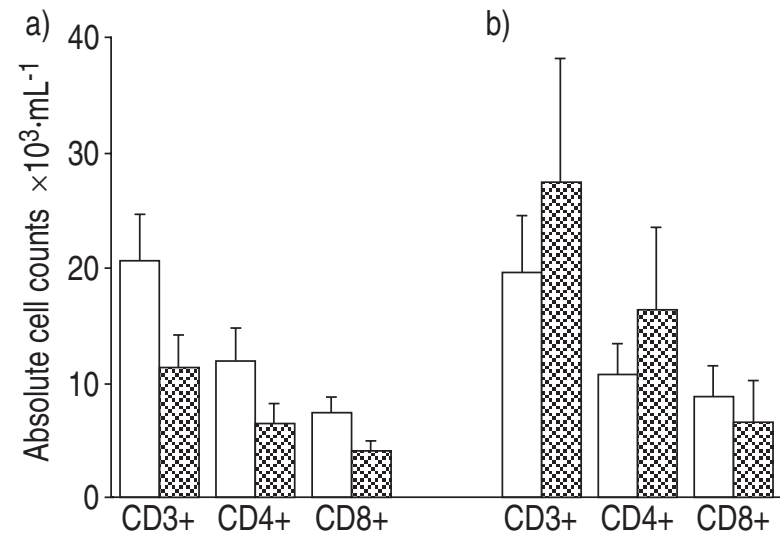

Fig. 2. - T-cell subpopulations in BAL of asthmatics pretreatment ( $\square$ ) and post-treatment ( $\square$ ) with either: a) theophylline (n=10); or b) placebo $(\mathrm{n}=7)$. Data are expressed as mean \pm SEM. Treatment-induced changes in the number of CD3+ T-cells were significantly different between the two groups $(\mathrm{p}<0.02)$. BAL: bronchoalveolar lavage.

after theophylline therapy compared to placebo, this difference did not attain significance, possibly due to the small study population used (table 3 ). There were no significant differences between the two treatment groups in the number of total nucleated cells, and in the percentage and concentration of eosinophils, neutrophils and epithelial cells. We were unable to make an accurate quantification of mast cells metachromatically, as too few (less than $0.1 \%$ ) were detectable in BAL fluid.

Flow cytometric analysis of BAL cells revealed a reduction in the number of $\mathrm{CD} 3+$ lymphocytes, comprising both CD4+ and CD8+ phenotypic subsets, after theophylline therapy and the difference between the two treatment groups was significant $(\mathrm{p}<0.02)$ (fig. 2). Moreover, there was a decrease in the number of CD4+ T-cells expressing the very late activation marker VLA-1 $(p<0.05)$, and a trend towards a decrease in CD4+ cells bearing the Class II molecule HLA-DR $(\mathrm{p}<0.1)$ (fig. 3). No differences were found between the treatment groups in

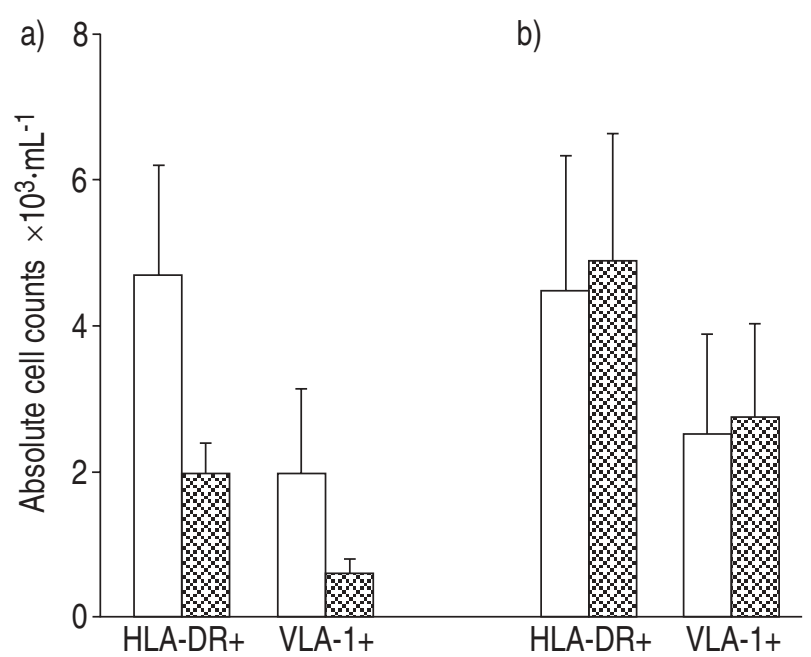

Fig. 3. - BAL CD4+ T-cells expressing activation markers pretreatment ( $\square$ ) and post-treatment ( $\square$ ) with either: a) theophylline (n= $10)$; or b) placebo $(n=7)$. Data are presented as mean \pm sEM. Treatmentinduced changes in the number of CD4+ T-cells expressing VLA-1 were significantly different between the two groups $(\mathrm{p}<0.05)$. HLADR: human leucocyte antigen-DR; VLA-1: very late activation antigen-1; BAL: bronchoalveolar lavage. the percentages of these cells. Moreover, there was no significant change between the two groups in the expression of all three activation markers by CD8+ T-cells (data not shown).

\section{Peripheral blood lymphocytes}

After theophylline therapy, there was a significant elevation in the percentage of CD4+ T-cells expressing HLA$\mathrm{DR}$ in peripheral blood samples obtained at baseline and during the EAR and LAR, when the two treatment groups were compared $(\mathrm{p}<0.05)$. The percentage of CD4+ cells bearing VLA-1 also tended to increase after theophylline but these results did not reach significance (table 4). Similar findings were obtained when comparisons in the absolute numbers of these cells were made between the two groups. Furthermore, no difference between the treatment groups could be determined in the percentage and concentration of CD3+ lymphocytes and their respective CD4+ and CD8+ subgroups, or in the expression of activation markers by CD8+ T-cells (data not shown).

\section{Discussion}

Our results provide evidence that 6 weeks of treatment with oral theophylline, at a low dose that is well-tolerated, can modulate T-lymphocyte activation in subjects with atopic asthma. We have shown that the number of lymphocytes in BAL, sampled after antigen challenge and the development of a LAR, was significantly reduced following theophylline therapy. On flow cytometric analysis, a loss in CD3+ T-lymphocytes, comprising both CD4+ and CD8+ phenotypic subsets, was revealed. Moreover, there was a decrease in the number of BAL CD4+ T-cells expressing the activation marker VLA-1, and an apparent reduction in HLA-DR. This was accompanied by an increase in the proportion of activated CD4+ T-lymphocytes in the peripheral blood.

These findings complement those of KIDNEY and coworkers [24, 25], who recently observed the opposite effects following theophylline withdrawal, that is a fall in the percentage of blood CD4+ T-cells bearing the activation marker CD25 and a concomitant increase of Tlymphocytes in the bronchial epithelium. Taken together, these results suggest that theophylline treatment can reduce the number of T-lymphocytes in the lungs of asthmatics, by modulating the egress and/or ingress of activated Tcells between the airways and circulation. This may be due to an action of the drug on lymphocyte adhesion and subsequent transendothelial migration. Compartmentalization of activated T-cells to the lung in asthma has been well-documented, and these results appear to correlate with clinical indices of disease activity [26, 27]. Recently, it has been demonstrated that these activated T-cells exhibit increased messenger ribonucleic acid encoding for interleukin (IL)-3, IL-4 and IL-5, thus suggesting that they are of the TH2-phenotype [16, 28].

In the current study, theophylline therapy appears to be associated with a reduction in the overall numbers of BAL CD4+ T-cells expressing activation markers but not a decrease in the proportion of these cells. This suggests 
Table 4. - Percentages of CD4+ T-cells expressing activation markers in peripheral blood

\begin{tabular}{|c|c|c|c|c|}
\hline & \multicolumn{2}{|c|}{ Theophylline group $(n=10)$} & \multicolumn{2}{|c|}{ Placebo group $(n=6)$} \\
\hline & $\begin{array}{c}\text { Pretreatment } \\
\%\end{array}$ & $\begin{array}{c}\text { Post-treatment } \\
\%\end{array}$ & $\begin{array}{c}\text { Pretreatment } \\
\%\end{array}$ & $\begin{array}{l}\text { Post-treatment } \\
\%\end{array}$ \\
\hline \multicolumn{5}{|l|}{ HLA-DR+ } \\
\hline EAR & $5.7 \pm 0.5$ & $6.9 \pm 0.7 *$ & $8.0 \pm 0.7$ & $7.5 \pm 0.8$ \\
\hline LAR & $5.6 \pm 0.5$ & $6.7 \pm 0.7 *$ & $7.0 \pm 0.5$ & $6.3 \pm 0.4$ \\
\hline $24 \mathrm{~h}$ & $5.7 \pm 0.6$ & $6.5 \pm 0.6$ & $7.6 \pm 0.7$ & $7.8 \pm 0.9$ \\
\hline \multicolumn{5}{|l|}{ VLA-1+ } \\
\hline Baseline & $1.3 \pm 0.3$ & $1.4 \pm 0.3$ & $1.2 \pm 0.5$ & $1.1 \pm 0.2$ \\
\hline EAR & $1.6 \pm 0.3$ & $1.4 \pm 0.3$ & $1.1 \pm 0.3$ & $1.0 \pm 0.2$ \\
\hline LAR & $1.5 \pm 0.3$ & $1.6 \pm 0.4$ & $1.1 \pm 0.3$ & $1.3 \pm 0.3$ \\
\hline $24 \mathrm{~h}$ & $1.6 \pm 0.3$ & $1.8 \pm 0.7$ & $1.2 \pm 0.3$ & $1.1 \pm 0.3$ \\
\hline
\end{tabular}

Blood samples were obtained at baseline, EAR, LAR and $24 \mathrm{~h}$ after antigen challenge pre- and post-treatment with theophylline or placebo. All values are presented as mean \pm SEM and are recorded as $\%$ of CD4+ T-cells. *: p<0.05, for comparison of treatment effect between groups. Baseline pretreatment values for the two groups were not significantly different. HLA-DR: human leucocyte antigen-DR; EAR: early asthmatic response; LAR: late asthmatic response; VLA-1: very late activation antigen-1.

that the drug may have modulated the movement both of activated and nonactivated lung CD4+ T-lymphocytes equally, rather than acting directly to inhibit the activated status of CD4+ cells.

There is increasing evidence of a key role for activated CD4+ T-lymphocytes in orchestrating the asthmatic inflammatory reaction. Through release of multifunctional cytokines, these cells upregulate the function of mast cells and eosinophils. Our present data failed to demonstrate any significant effect of theophylline on the number of eosinophils, neutrophils and epithelial cells in BAL fluid after allergen challenge, although the concentration of macrophages was apparently reduced compared to the placebo-treated group. Moreover, although within the constraints of the number of subjects studied there was no significant decrease in the concentration of inflammatory mediators in the BAL fluid, a general downward trend in the levels of these mediators, such as ECP, was observed following theophylline treatment. However, in a complementary publication [23], we have described a significant reduction after theophylline therapy in the number of total eosinophils and EG2+ cells (an index of eosinophil activation) in bronchial biopsies of essentially the same group of subjects. Elevated levels of eosinophils, both in the bronchial mucosa and in BAL fluid, are a characteristic feature of asthma, and this eosinophilia correlates with the severity of the disease [26, 29, 30]. Through their secretion of granule-derived cationic proteins and lipid mediators, eosinophils may contribute to the development of the LAR to allergen and the associated bronchial hyperresponsiveness [31]. The recruitment and degranulation of eosinophils in the bronchial mucosa are thought to be under the influence of cytokines produced by activated T-cells, particularly IL-3, IL-5 and granulocyte-macrophage colony-stimulating factor $[17$, 32-34]. Our present data suggests that theophylline therapy can modulate the activation of T-lymphocytes in the lung, and it is possible that this would in turn reduce the influx and activation of eosinophils.

The precise molecular mechanism of action of theophylline remains uncertain, but perhaps the most likely explanation is its nonspecific inhibition of phosphodiesterase activity [35]. Indeed, modulation of intracellular cyclic nucleotide levels has been demonstrated to functionally modify the activity of many inflammatory cell types [36].

An immunoregulatory action for theophylline, at the currently recognized therapeutic concentrations (10-20 $\left.\mu \mathrm{g} \cdot \mathrm{mL}^{-1}\right)$, has been documented both in vivo and in vitro. In these studies, the drug was demonstrated to increase the number and activity of suppressor/cytotoxic T-cells, particularly in asthmatics [37-40], to inhibit natural killer cell activity [41, 42], and to reduce T-cell proliferation and IL-2 production [43]. Theophylline, therefore, appears at therapeutic levels to have a general immunosuppressive action. The lower doses (range $4.0-8.3 \mu \mathrm{g} \cdot \mathrm{mL}^{-1}$ ) achieved in the present study, however, may be sufficient for a beneficial immunomodulatory action in asthma without the side-effects that currently limit the use of this drug. In addition, theophylline may have a more selective effect on activated CD4+ T-cells at low concentrations, as no significant change in the number of CD8+ cells expressing activation markers was observed in this study.

Low-dose oral theophylline treatment reduces the number of T-lymphocytes in the airways of asthmatics. The mechanism by which this action is achieved is currently unclear, but may be a consequence of the drug modulating the accumulation of CD4+ T-cells in the lung and their subsequent activation. These effects may contribute to the therapeutic efficacy of theophylline in asthma.

Acknowledgements: The authors thank E. Davies, H. Jones and M. Peakman of the Department of Immunology, King's College School of Medicine and Dentistry for expert technical assistance and G. Mackay for critical reading of the manuscript.

\section{References}

1. Pepys J, Hutchcroft BJ. Bronchial provocation tests in etiologic diagnosis and analysis of asthma. Am Rev Respir Dis 1975; 12: 829-859.

2. Booij-Noord H, de Vries K, Sluiter HJ, Orie NGM. Late bronchial obstructive reaction to experimental inhalation of house dust extract. Clin Allergy 1972; 2: 43-61.

3. O'Byrne PM, Dolovich J, Hargreave FE. Late asthmatic responses. Am Rev Respir Dis 1987; 136: 740-751. 
4. Casale TB, Wood D, Richerson HB, Zehr B, Zavala D, Hunninghake GW. Direct evidence of a role for mast cells in the pathogenesis of antigen-induced bronchoconstriction. J Clin Invest 1987; 80: 1507-1511.

5. Holgate ST, Finnerty JP. Recent advances in understanding the pathogenesis of asthma and its clinical implications. Q J Med 1988; 149: 5-19.

6. De Monchy JGR, Kauffman HF, Venge P, et al. Bronchoalveolar eosinophilia during allergen-induced late asthmatic reactions. Am Rev Respir Dis 1985; 131: 373-376.

7. Kirby JG, Hargreave FE, Gleich GJ, O'Byrne PM. Bronchoalveolar cell profiles of asthmatic and nonasthmatic subjects. Am Rev Respir Dis 1987; 136: 379-383.

8. Beaseley R, Roche WR, Roberts JA, Holgate ST. Cellular events in the bronchi in mild asthma and after bronchial provocation. Am Rev Respir Dis 1989; 139: 806-817.

9. British Thoracic Society Guidelines on the Management of Asthma. Thorax 1993; 48: S1-24.

10. Nielson CP, Crowley JJ, Cusack BJ, Vestal RE. Therapeutic concentrations of theophylline and enprofylline potentiate catecholamine effects and inhibit leukocyte activation. J Allergy Clin Immunol 1986; 78: 660-667.

11. Condino-Neto A, Vitela MMS, Cambiucci EC, et al. Theophylline therapy inhibits neutrophil and mononuclear cell chemotaxis from chronic asthmatic children. Br J Clin Pharmacol 1991; 32: 557-561.

12. Venge P, Dahl R, Karlstrom R, Pedersen B, Peterson CGB. Eosinophil and neutrophil activity in asthma in a one year double-blind trial with theophylline and two doses of inhaled budesonide. J Allergy Clin Immunol 1992; 89: A181 (Abstract).

13. Pauwels R, Van Renterghan D, Van Der Straeten M, Johannesson N, Persson CGA. The effect of theophylline and enprofylline on allergen-induced bronchoconstriction. J Allergy Clin Immunol 1985; 76: 583-590.

14. Crescioli S, Spinazzi A, Plebani M, et al. Theophylline inhibits early and late reactions induced by allergens in asthmatic subjects. Ann Allergy 1991; 66: 245-251.

15. Ward AJM, Mckenniff M, Evans JM, Page CP, Costello JF. Theophylline: an immunomodulatory role in asthma? Am Rev Respir Dis 1993; 147: 518-523.

16. Robinson DS, Hamid Q, Ying S, et al. Evidence for a predominant "TH2-type" bronchoalveolar lavage T-lymphocyte population in atopic asthma. $N$ Engl J Med 1992; 326: 298-304

17. Corrigan CJ, Kay AB. T-cells and eosinophils in the pathogenesis of asthma. Immunol Today 1992; 13: 501-507.

18. Holgate ST. Mediator and cytokine mechanisms in asthma. The Altounyan Address. Thorax 1993; 48: 103-110.

19. Corrigan CJ, Hartnell A, Kay AB. T-lymphocyte activation in acute severe asthma. Lancet 1988; i: 1129-1131.

20. Gerblich AA, Campbell AE, Schuyler MR. Changes in T-lymphocyte subpopulations after antigenic bronchial provocation in asthmatics. N Engl J Med 1984; 310: 1349-1352.

21. Gerblich AA, Salik H, Schuyler MR. Dynamic T-cell changes in peripheral blood and bronchoalveolar lavage after antigen bronchoprovocation in asthmatics. Am Rev Respir Dis 1991; 143: 533-537.

22. Gonzalez MC, Diaz P, Galleguillos FR, Ancic P, Cromwell $\mathrm{O}$, Kay AB. Allergen-induced recruitment of bronchoalveolar helper (OKT4) and suppressor (OKT8) T-cells in asthma. Am Rev Respir Dis 1987; 136: 600-604.

23. Sullivan P, Bekir S, Jaffar Z, Page C, Jeffery P, Costello J. Anti-inflammatory effects of low-dose oral theophylline in atopic asthma. Lancet 1994; 343: 1006-1008.

24. Kidney JC, Dominguez M, Rose M, Aikman S, Chung
KF, Barnes PJ. Immune modulation by theophylline: the effect of withdrawal of chronic treatment in asthma. Am Rev Respir Dis 1993; 147: A772 (Abstract).

25. Kidney JC, Dominguez M, Rose M, Aikman S, Chung $\mathrm{KF}$, Barnes PJ. Withdrawing chronic theophylline treatment increases airway lymphocytes in asthma. Thorax 1994; 49: 396 (Abstract).

26. Azzawi M, Bradley B, Jeffery PK, et al. Identification of activated T-lymphocytes and eosinophils in bronchial biopsies in stable atopic asthma. Am Rev Respir Dis 1990; 142: 1407-1413.

27. Wilson JW, Djukanovic R, Howarth PH, Holgate ST. Lymphocyte activation in bronchoalveolar lavage and peripheral blood in atopic asthma. Am Rev Respir Dis 1992; 145: 958-960.

28. Hamid Q, Azzawi M, Ying S, et al. Expression of mRNA for interleukin-5 in mucosal bronchial biopsies from asthma. J Clin Invest 1991; 87: 1541-1546.

29. Wardlaw AJ, Dunnette S, Gleich GJ, Collins JV, Kay AB. Eosinophils and mast cells in bronchoalveolar lavage in mild asthma: relationship to bronchial hyperreactivity. Am Rev Respir Dis 1988; 137: 62-69.

30. Bousquet J, Chanez P, Lacoste JY, et al. Eosinophilic inflammation in asthma. N Engl J Med 1990; 323: 1033-1039.

31. Durham SR, Kay AB. Eosinophils, bronchial hyperreactivity and late-phase asthmatic reactions. Clin Allergy 1985; 15: 411-418.

32. Rothenburg ME, Owen WF, Silberstein DS, et al. Human eosinophils have prolonged survival, enhanced functional properties and become hypodense when exposed to human interleukin-3. J Clin Invest 1988; 81: 1986-1992.

33. Lopez AF, Sanderson CJ, Gamble JR, Campbell HD, Young IG, Vadas MA. Recombinant human interleukin5 as a selective activator of human eosinophil function. J Exp Med 1988; 167: 219-224.

34. Owen WF, Rothenburg ME, Silberstein DS, et al. Regulation of human eosinophil viability, density and function by granulocyte/macrophage colony-stimulating factor in the presence of 3T3 fibroblasts. J Exp Med 1987; 166: 129-141.

35. Persson CGA. Overview of effects of theophylline. $J$ Allergy Clin Immunol 1986; 78: 780-787.

36. Torphy TJ, Undem BJ. Phosphodiesterase inhibitors: new opportunities for the treatment of asthma. Thorax 1991; 46: 512-523.

37. Fink G, Mittleman M, Shohat B, Spitzer SA. Theophyllineinduced alterations in cellular immunity in asthmatic patients. Clin Allergy 1987; 17: 313-316.

38. Pardi R, Zocchi MR, Ferrero E, Ciboddo GF, Inverardi L, Rugarli C. In vivo effects of a single infusion of theophylline on human peripheral blood lymphocytes. Clin Exp Immunol 1984; 57: 722-728.

39. Shohat B, Volovitz B, Varsano I. Induction of suppressor T-cells in asthmatic children by theophylline treatment. Clin Allergy 1983; 13; 487-493.

40. Ilfeld D, Kivity S, Feierman E, Topilsky M, Kuperman O. Effect of in vitro colchicine and oral theophylline on suppressor cell function of asthmatic patients. Clin Exp Immunol 1985; 61: 360-367.

41. Coskey LA, Bitting J, Roth MD. Inhibition of natural killer cell activity by therapeutic levels of theophylline. Am J Respir Cell Mol Biol 1993; 9: 659-665.

42. Yokoyama A, Yamashita N, Mizushima Y, Yano S. Inhibition of natural killer cell activity by oral administration of theophylline. Chest 1990; 98: 924-927.

43. Scordamaglia A, Ciprandis G, Ruffoni S, et al. Theophylline and the immune response: in vitro and in vivo effects. Clin Immunol Immunopathol 1988; 48: 238-246. 